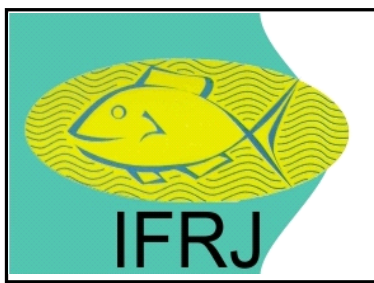

Available online at: http://ejournal-balitbang.kkp.go.id/index.php/ifrj

$$
\text { e-mail:ifrj.puslitbangkan@gmail.com }
$$

INDONESIANFISHERIES RESEARCHJOURNAL

Volume 23 Nomor 2 December 2017

e-ISSN: 2502-6569

Accreditation Number: 704/AU3/P2MI-LIPI/10/2015

\title{
GENETIC DIVERSITY OF MACKEREL SCADS, Decapterus macarellus (Cuvier, 1833) IN THE INDIAN OCEAN
}

\author{
Achmad Zamroni ${ }^{\star 1}$ and Suwarso ${ }^{1}$ \\ ${ }^{1}$ Peneliti pada Balai Penelitian Perikanan Laut, Komp. Raiser Ikan Hias \\ JI. Raya Bogor KM. 47 Nanggewer Mekar, Cibinong, Jawa Barat-Indonesia \\ Received; April 21-2017 Received in revised from January 18-2018; Accepted January 30-2018
}

\begin{abstract}
Mackerel scads (Decapterus macarellus) is a small widely distributed pelagic species in ocean. In 2013, monthly catch and abundance index of mackerel scads increased in western part of Sumatera waters. High exploitation of mackerel scads may lead to decrease stock due to the over exploitation. Stock information is very useful for calculating of the potential fish. Genetic analysis is one of the powerful tools to estimate fish stock quickly. Genetic diversity of mackerel scads in this study was analyzed using RFLP (Restriction Fragment Length Polymorphism) with Afal, EcoR I, Hapll, Hinfl and Taql restriction enzyme. The results showed that the lowest genetic diversity of mackerel scads was Labuan population. Kinship Labuan was also the furtherest stock compared to other populations. It can be concluded that the population of Labuan is derived from a different sub-species. The closest kinship was between Aceh and Sibolga stock.
\end{abstract}

Keyword: Mackerel; Decapterus; genetic; DNA; Indian Ocean

\section{INTRODUCTION}

Mackerel scads or malalugis (Decapterus macarellus), is a high economic small pelagic species widespread in the deep sea of the Indian Ocean e.g. Western and Eastern part of Indonesia (Hariati, 2005). The exploitation of mackerel scads is now already overfishing and uncontrolled (Suwarso et al., 2000). Mostly purse seine is used in West Aceh, Sibolga and Kupang, lift net is also used to catch juvenile in Sibolga. In 2013, monthly catch and abundance index of mackerel scads in the west of Sumatera waters was 17,226 ton higher than 2012 which was 16,782 ton.

Over exploitation of mackerel scads in the Indian Ocean still exist while the data of potential production is not available. Stock unit of mackerel scads in the Indian Ocean is very important to understand their relationship and origin. A common method in fishery to clarify fish stocks is the analyses data of the following parameters: length, frequency distribution, length weight relationship, condition factor, age, growth, mortality and the rate of exploitation. Genetic analysis is one of the powerful tools to estimate fish stock quickly (Utter et al., 1987), especially for the inter-regional management units of important marine species (Giles et al., 2014). Santos et al. (2010) stated that the genetic diversity is enables to determine the status of the population.

Stock maintaining is very important for sustainable yield and conservation of genetic resources. Fisheries management based on the population genetic structure approach is needed. Mt-DNA genome of fish has a high degree of polymorphism containing information related to population unit, phylogeographic, migration patterns, hybridization and systematic and barcode (Ferris \& Berg, 1987; Bermingham, 1990). Various fragment DNA analysis is applied now and small sequences is more preferred. Specific site of mt DNA is resulted from restriction enzymes work producing polymorphic profile for relationships analysis. The purpose of this study was to analyses the population diversity of mackerel scads (Decapterus macarellus) in the waters of the Indian Ocean using RFLP (Restriction Fragment Length Polymorphism) DNA method.

\section{MATERIALS AND METHODS Sampling}

Sampling was conducted at four fish landing sites: 1) Kupang, South of Kupang;2) Labuan, Sunda Strait; 3) Sibolga, West of Sibolga; and 4) Lampulo, West of Aceh (Figure 1). Twenty four mackerel scads were 
collected at each site, total 96 samples. Approximately $1 \times 1 \times 1 \mathrm{~cm}$ muscle from dorsal part was collected from each fish. The samples were preserved in appendorf tubes containing $96 \%$ ethanol and then were stored at room temperature for further DNA analysis at genetics laboratory of Research Institute for Marine Fisheries.

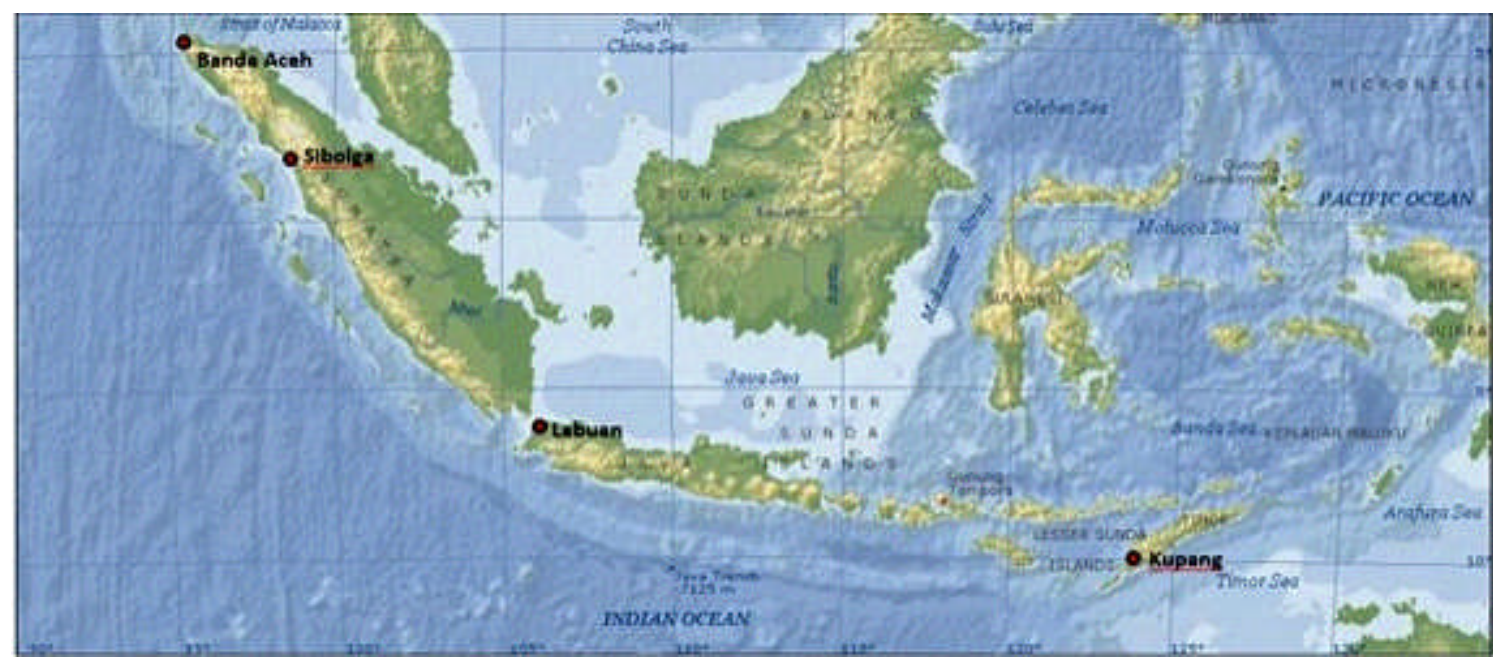

Figure 1. Sampling sites of mackerel scads (D. macarellus) in Indian Ocean.

\section{Sample Analysis}

The analysis was performed by using RFLP (Restriction Fragment Length Polymorphism) method (Fatchiyah et al., 2011). Extraction and purification process were implemented by the method of minicolumn from PureLink ${ }^{\mathrm{TM}}$ Genomic DNA Kits, Invitrogen ${ }^{\mathrm{TM}}$. The amplification (PCR) process using the primer of HN20 $=5$-GTGTTATGCTTTAGTTAAGC3', and LN20 = 5'-ACCACTAGCACCCAAAGCTA-3'. Cycle on the PCR process set up as follows: 1 cycle of denaturation at $94^{\circ} \mathrm{C}$ for $2 \mathrm{~min}, 35$ cycles of doubling consisting of $94^{\circ} \mathrm{C}$ for $1 \mathrm{~min}, 48^{\circ} \mathrm{C}$ for 1 minute and $72^{\circ} \mathrm{C}$ for 1 minute; and then the last cycle at $72{ }^{\circ} \mathrm{C}$ for 5 minutes. Restriction enzymes are used consisting of 5 types, Afa I, EcoR I, Hap II, Hinf I and Taq I. Restrictions made to the sequences amplified from mitochondrial DNA (mtDNA) D-loop control region.

\section{Data Analysis}

The results of each restriction enzyme on individual samples (96 samples) obtained types haplotype. Types haplotype of each sample was analyzed by software TFPGA (Tools For Population Genetic Analyzes) (Miller, 1997) which includes the analysis of haplotype diversity, kinship between populations through pairwise distance test (FST), a distance of genetics and kinship between populations are presented in the form of a dendrogram. Haplotype diversity analysis conducted by Nei \& Tajima (1981) by the equation:

$$
h=\frac{n}{n-1}\left(1-\sum X_{i}^{2}\right)
$$

where;

$\mathrm{h}=$ haplotype diversity

$\mathrm{n}=$ number of samples

$X_{1}=$ haplotype frequency samples

Genetic distance is a measure of genetic differences between populations were calculated based on the frequency of haplotypes per population. The calculation of genetic distance by Nei \& Tajima (1981) through the TFPGA by the equation:

$D=-\ln \left\{J_{a b} /\left\{\left(J_{a} \times J_{b}\right)^{0,5}\right\}\right]$

where;

$\mathrm{D}=$ Genetics distance

$\mathrm{J}_{\mathrm{ab}} \quad=$ Loci haplotype frequencies in the same population

$J_{a} \& J_{b}=$ Haplotype frequencies in populations $A$ and B

Dendrogram kinship between populations based on haplotype diversity, kinship between species in the population, kinship between populations through pairwise distance test (FST) and cluster analysis of the genetic distance value according to the average distance method UPGMA (Unweight Pair Group Methods Arithmatec) (Bermingham, 1990) by using software TFPGA (Miller, 1997). 


\section{RESULTS AND DISCUSSION} Results

Electrophoresis of five restriction enzymes produced 13 genotypes of DNA fragments (Table 1). The result of Taq I enzymes is in Figure 2 showing three restriction sites.

Genotype of mackerel scads is presented in Table 2 and it is known that for all enzymes used to produce
DNA fragments type $A$ and $B$. C type fragments are only produced by the EcoR $V$ and Taq I enzymes.

Based on the obtained restriction sites, nine genotypes of alleles/haplotypes were recognized as AAAAA, AAABA, ABAAA, ABABA, ACAAA, ACAAB, ADAAA, BBAAC and BBBAC. Haplotype diversity ranged from 0.0310 to 0.2522 and mean was 0.1667 (Table 3).

Table 1. Genotypes of DNA resulted from five restriction enzymes Afa I, EcoR V, Hap II, Hinf I dan Taq I.

\begin{tabular}{|c|c|c|c|c|c|c|c|c|c|c|c|c|c|}
\hline \multirow{3}{*}{$\begin{array}{l}\text { Length of } \\
\text { Fragment } \\
\text { (bp) }\end{array}$} & \multicolumn{13}{|c|}{ Enzyme } \\
\hline & \multicolumn{2}{|c|}{ Afa I } & \multicolumn{4}{|c|}{ EcoR V } & \multicolumn{2}{|c|}{ Hap II } & \multicolumn{2}{|c|}{ Hinf I } & \multicolumn{3}{|c|}{ Taq I } \\
\hline & A & B & A & B & C & D & A & B & A & B & A & B & C \\
\hline 800 & & & & & & & & & & & & & \\
\hline 750 & & & & & & & & & & & & & \\
\hline 700 & & & & & & & & & $\ldots$ & & & & \\
\hline 650 & & & & & & & & & & & & & \\
\hline 600 & & & & - & & & & & & 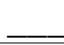 & & & \\
\hline 550 & & & & & & & & & & & & & \\
\hline 500 & & & & & & & & & & & & & \\
\hline 450 & & & & & & & 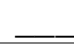 & 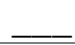 & & & & & \\
\hline 400 & & & & & & & & & & & - & & \\
\hline 350 & $\overline{-}$ & & $\overline{\bar{E}}$ & & & & & & & & & & $\overline{\bar{~}}$ \\
\hline 300 & & & & & $\overline{\bar{\nu}}$ & & & & & & & & \\
\hline 250 & & & & & & & & & & & & & \\
\hline 200 & 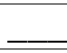 & & & & & & 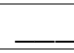 & & & & & $\overline{\bar{C}}$ & \\
\hline 150 & & & & 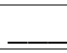 & & $\overline{\bar{~}}$ & & & & 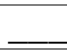 & - & - & \\
\hline 100 & $\overline{\bar{~}}$ & $\overline{\bar{~}}$ & & & 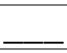 & & & $\overline{\bar{C}}$ & & & $\overline{\bar{C}}$ & $\overline{\bar{C}}$ & \\
\hline 50 & & $\overline{ }$ & 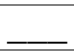 & & $\bar{L}$ & 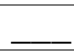 & $\overline{\bar{C}}$ & $\overline{\bar{Z}}$ & 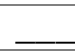 & & $\overline{7}$ & $\bar{\Gamma}$ & - \\
\hline $\begin{array}{l}\text { Number } \\
\text { or } \\
\text { fragment }\end{array}$ & 4 & 4 & 3 & 2 & 4 & 4 & 4 & 5 & 2 & 2 & 4 & 5 & 3 \\
\hline $\mathbf{N}$ & 72 & 24 & 34 & 54 & 6 & 2 & 94 & 2 & 74 & 22 & 70 & 2 & 24 \\
\hline
\end{tabular}

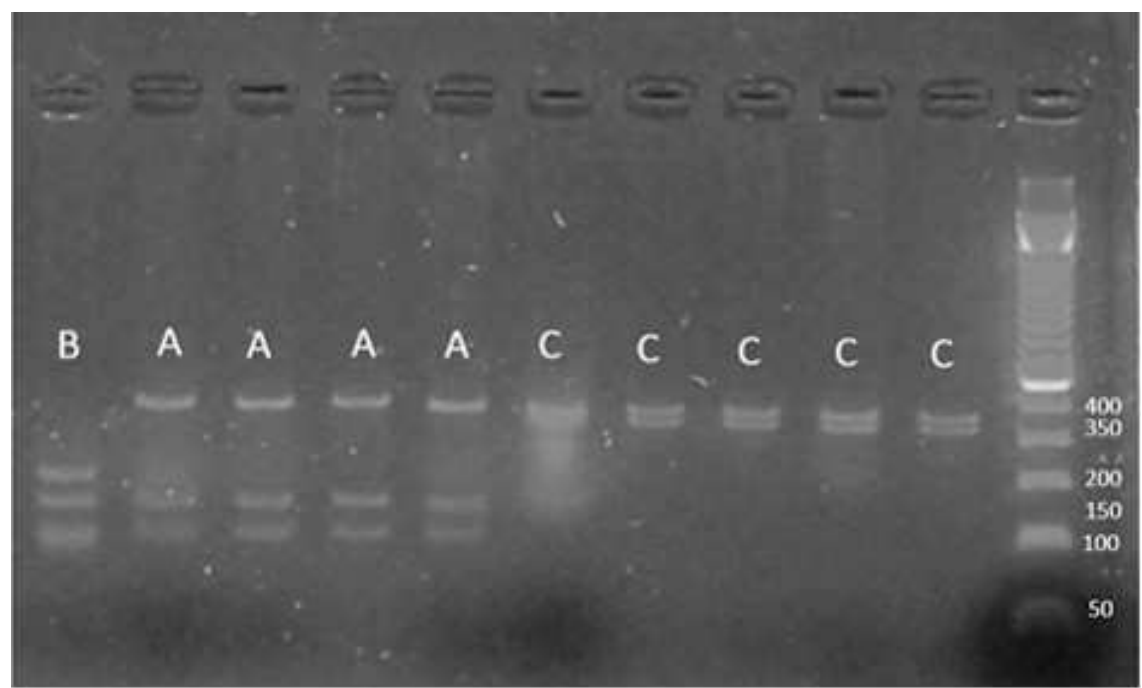

Figure 2. Results of restriction of mackerel scads DNA from Labuan with Taq 1 enzyme (three types of restriction $\mathrm{A}, \mathrm{B}$ and $\mathrm{C}$ ). 
Ind.Fish.Res.J. Vol. 23 No. 2 December 2017: 89-96

Table 2. Genotype distribution (type of restriction) in four Mackerel scads populations

\begin{tabular}{|c|c|c|c|c|c|}
\hline Enzyme & $\begin{array}{l}\text { Type of } \\
\text { restriction }\end{array}$ & Kupang & Sibolga & Labuan & Aceh \\
\hline Afa I & $\begin{array}{l}\text { A } \\
B\end{array}$ & 24 & 24 & 24 & 12 \\
\hline EcoR V & $\begin{array}{l}\text { A } \\
B \\
C \\
D\end{array}$ & $\begin{array}{c}16 \\
6 \\
2\end{array}$ & $\begin{array}{c}10 \\
12 \\
2\end{array}$ & 24 & $\begin{array}{c}8 \\
12 \\
2 \\
2\end{array}$ \\
\hline Hap II & $\begin{array}{l}\text { A } \\
B\end{array}$ & 24 & 24 & $\begin{array}{c}22 \\
2\end{array}$ & 24 \\
\hline Hinf I & $\begin{array}{l}\text { A } \\
B\end{array}$ & $\begin{array}{c}20 \\
4\end{array}$ & $\begin{array}{l}14 \\
10\end{array}$ & 24 & $\begin{array}{c}16 \\
8\end{array}$ \\
\hline Taq I & $\begin{array}{l}A \\
B \\
C\end{array}$ & 24 & $\begin{array}{c}22 \\
2\end{array}$ & 24 & 24 \\
\hline
\end{tabular}

Table 3. Haplotype of the mtDNA D-loop of mackerel scad (Decapterus macarellus) in the Indian Ocean

\begin{tabular}{|c|c|c|c|c|c|}
\hline \multirow{2}{*}{ No. } & \multirow{2}{*}{ Composite Haplotype } & \multicolumn{4}{|c|}{ Haplotype Freq. } \\
\hline & & Kupang & Sibolga & Labuan & Aceh \\
\hline 1 & AAAAA & 0.58 & 0.417 & & 0.333 \\
\hline 2 & AAABA & 0.083 & & & \\
\hline 3 & ABAAA & 0.167 & 0.083 & & 0.167 \\
\hline 4 & ABABA & 0.083 & 0.417 & & 0.333 \\
\hline 5 & ACAAA & 0.083 & & & 0.083 \\
\hline 6 & ACAAB & & 0.083 & & \\
\hline 7 & ADAAA & & & & 0.083 \\
\hline 8 & BBAAC & & & 0.917 & \\
\hline 9 & BBBAC & & & 0.083 & \\
\hline & $\mathrm{N}$-alelle & 5 & 4 & 2 & 5 \\
\hline & lotype Diversity & 0.1594 & 0.2522 & 0.0319 & 0.2232 \\
\hline
\end{tabular}

Pair wise distance method $\left(\mathrm{F}_{\mathrm{ST}}\right)$, showed that there Genetic distance showed that Labuan population has is a significant different between Labuan population furthest relationships among populations observed with others from Kupang, Sibolga and Aceh (Table 4). (Table 5 and Figure 3).

Table 4. Inter population analysis of Decapterus macarellus pair wise distance method

\begin{tabular}{|c|c|c|c|c|}
\hline & Kupang & Sibolga & Labuan & Aceh \\
\hline Kupang & $\star \star \star \star * \star *$ & & & \\
\hline Sibolga & $0.5548^{\text {ns }}$ & 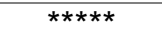 & & \\
\hline Labuan & $0.0000^{s}$ & $0.0000^{s}$ & $\star * * * *$ & \\
\hline Aceh & $0.6456^{\text {ns }}$ & $0.9854^{\mathrm{ns}}$ & $0.0000^{s}$ & $\star * \star * *$ \\
\hline
\end{tabular}

Remarks: ns: not significantly different $(\mathrm{P}>0,05)$; $\mathrm{n}$ : significantly different $(\mathrm{P}<0,05)$ 
Table 5. 'Nei' genetic distance of Decapterus macarellus in the Indian Ocean.

\begin{tabular}{lcccc}
\hline & Kupang & Sibolga & Labuan & Aceh \\
\hline Kupang & $* * * *$ & & & \\
\hline Sibolga & 0.0319 & ${ }^{* * * *}$ & & \\
\hline Labuan & 0.8179 & 0.7625 & ${ }^{* * * *}$ & \\
\hline Aceh & 0.0286 & 0.0052 & 0.7396 & $* * * *$ \\
\hline
\end{tabular}

Genetic relationship showed that the four and Kupang and the second one was only Labuan populations can be separated into two groups, the first group consists of a population of Sibolga, Aceh population Labuan.

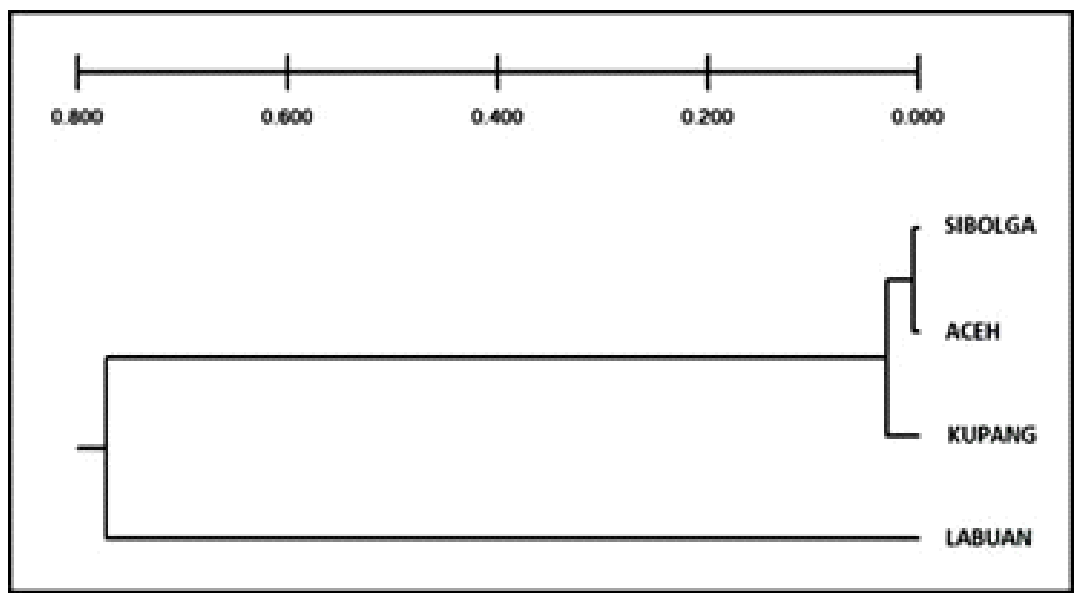

Figure 3. Dendrogram phylogeny of 4 populations of $D$. macarellus in Indian Ocean.

\section{Discussion}

Kinship Decaptarus macarellus from four populations showed that the population of Aceh, Sibolga and Kupang included in one group of the population, while the population of Labuan included in another group. Genetically the population of Labuan differs from the other three populations. The distance of Aceh and Sibolga is geographically close, yet far enough away from the location of Kupang, but still allow the gene flow from Kupang to Aceh and Sibolga (west coast of Sumatera). Mackerel scads is small pelagic fish that is oceanic, and migrate widely. Allegedly the location of Aceh, Sibolga and Kupang is the migration path of scads mackerel in the waters of the Indian Ocean. Allegedly Mackerel scads in Labuan originated from the Indian Ocean that settled in the waters of the Sunda Strait and genotypically adaptation occurred. The waters of the Sunda Strait is a dynamic strait. The northern part of the strait which is directly related to the Java Sea has the dominant influence of water masses from the Java Sea and South China Sea, while in the southern part of the waters is strongly influenced by the conditions of the Indian Ocean waters (Wyrtki, 1962). According to Birowo (1983) Sunda Strait lies between the island of Sumatra and Java Island where the mass of Java Sea water mixed with the mass of water from the Indian Ocean. This causes the fish to adapt, causing genotyping genes that were originally mutations in only one individual of the individual population constituents to undergo change (Sofro, 1994). The migration process is influenced by two factors: internal and external. Internal factors include the form of metabolic equilibrium such as migration for food and external factors including the current, temperature and salinity. Susanto et al. (2001) stated that in the month of June to October upwelling occurs along the waters south of Java to western of Sumatra. This upwelling process is a response to the monsoon cycle. In June, the southeast monsoon winds cause upwelling and the erosion of the thermocline in the waters of East Java. The upwelling spread westward to the tip of Sumatra and moved closer to the equator during the months of June to October. Wyrtki (1961) suggested that in July to October, East Monsoon Winds push the South Equatorial Currents (SEC) to the north. SEC were pushed to the north in the period suspected of spreading mass of cold water and high salinity coming from upwelling spreading further north.

According to Pfenninger et al. (2011) factors potentially shaping genetic diversity are geographical marginality, environmental marginality, habitat size, potential biotic interactions, range expansions and dispersal barriers. Liu et al. (2013) suggest that ecological factors can have strong impacts on both population size per se and intrapopulation genetic 
variation even at a small scale. On a more general level, our data indicate that a patchy environment and low dispersal rate can result in fine-scale patterns of genetic diversity. The number of types of composite haplotypes effect on genetic diversity in a population, the more the number of types of composite haplotype diversity will be higher, and vice versa. The value of genetic diversity can be seen from the value of haplotype diversity. Haplotype diversity value obtained from this study is 0.0319 to 0.2522 , these values lower than studies conducted in the waters around Sulawesi for the same species, which ranges from 0.3698 (Zamroni et al., 2014), and lower than other marine fish species, such as yellow fin tuna in Maluku is 0.984 to 1.00 (Akbar et al., 2014) and grouper at 0.7749 to 0.7940 (Sembiring et al., 2013). According Avise et al. (1989) in Tabata et al. (1997) mention that the whole mtDNA haplotype diversity for some fish are in the range of 0.473 to 0.998 . Low genetic diversity (haplotype diversity) in this study because the sampling sites are interconnected (Southern Indian Ocean, Sunda Strait and the Indian Ocean west of Sumatra). Fishing pressure on mackerel scads fish can also cause a reduction in the genetic diversity of a species. According to Wilson \& Clarke (1996), the increasing exploitation and pressure on the environment can lead to a decline in stock abundance and average size of the fish; adverse genetic selection against potential fecundity; reducing the average size of the spawn; changing the sex ratio and balance interspecific; and the loss of genetic diversity. High genetic diversity in the population will have a better chance of survival because each gene has a different response to environmental conditions. Hartl \& Jones (1998) stated that the high genetic diversity in the population of fish may protect from environmental interference.

The lowest number of composite haplotype is the population of Labuan which consists of two types, while the highest number of composite haplotype is belong to Kupang and Aceh populations, which consists of five types. Low composite haplotypes / genetic diversity in Labuan is apparently due to the exploitation of mackerel scads fish intensified, and the condition of the Sunda Strait which is less wide (narrow). The results of Octoriani, (2015) is study show that the actual exploitation of multispecies in the Sunda Strait caught in purse seine has already occurred over exploitation. The results are supported by a low survival rate, which is suspected because of the high pressure of catching. The length of first captured (Lc) is smaller than the length of the first mature gonad (Lm). The optimal effort (EMEY) result of bioeconomic analysis of competition is smaller than EMEY without considering the inter-species relationship. The results of the bioeconomic analysis show that species of Goldstripe sardinella, mackerel, neritic tuna, and scads are indicated to have undergone biological overfishing and economic overfishing. Exploitation may lead to an increased rate of genetic drift, in addition to the small population tends to occur inbreeding, which can adversely affect the survival of the population. The indication is the decline in the genetic diversity of the population, namely the decline in haplotype diversity and nucleotide diversity (Zein, 2007). A decrease in the genetic variability could endanger the survival of the population because it can reduce the ability of the individual in the face of natural selection pressures, mainly due to changes in the environment (Hedrick, 2000). Allendorf et al. (2008) said that catching the fish populations potentially against the three genetic changes: changing population structure, genetic variation selective genetic. Dammannagoda et al. (2011) said that to maintain the productivity of the fish population, it is imperative to incorporate the genetic consideration in fisheries management. The management plan should be developed by applying the basic principles of genetics combined with molecular genetic monitoring to minimize harmful genetic changes. Understanding the genetic changes and evolutionary response of the exploited population is also important to design management strategies aimed at sustainable use of biological resources (Walsh et al., 2006). This study shows that there are two main populations structures, so that, in the management of mackerel scad fish, it is recommended to use a different method to approach each population group. Labuan populations that have low genetic diversity and narrow waters emphasis on conservation, for example, by regulation the fishing season and the closure of fishing areas. The population of Aceh, Sibolga and Kupang who have extensive water areas and higher genetic diversity of a population of Labuan. For that is expected in the waters of these three populations genetic diversity can be maintained by not exploiting small-sized fish. One way is to use fishing gear that has a high selectivity, for example, restrictions on mesh size and the size of the mouth of the trap.

\section{CONCLUSION}

The genetic diversity of mackerel stock in Indian Ocean is low with the index in the range 0.0310 to 0.2522 . The Indian Ocean consisted of two stock mackerel scads, the first stock is derived from three sites/location Aceh, Kupang and Sibolga, and the other stock from Labuan. The Indian Ocean is the migration path of mackerel scad. 


\section{ACKNOWLEDGEMENT}

This study is part of research activity entitled "Research Stock, Distribution and Biological Parameters Small Pelagic Fish Resources" in WPP 572 and 573, in the 2013 at Research Institute for Marine Fisheries, Jakarta. We would like to thank you to Rino who helped sample analysis. We also thank to the technicians from Research Institute for Marine Fisheries (RIMF): Hari, Fadli and Arlini, who collect samples to Fauzi, Herlisman and Taufik who contribute idea to write this paper. May Allah bless you all.

\section{REFERENCES}

Akbar, N., Zamani, N. P., \& Madduppa, H. W. (2014). (In Indonesian). Genetic diversity of yellowfin tuna (Thunnus albacares) from two populations in the Maluku Sea, Indonesia. Depik, 3(1), 65-73.

Allendorf, F. W., England, P. R., Luikart, G., \& Ritchie, P.A. (2008). Genetic effects of harvest on wild animal populations. Trends in Ecol. Evol, 23, 327337.

Avise, J. C., Bowen, B. W., \& Lamb, T. (1989). DNA fingerprints from hypervariable mitochondrial genotypes. Molecular Biology Evolution, 6, 258269.

Bermingham, E. (1990). Mitochondrial DNA and the Analysis of Fish Population Structure. In: D. H. Whitmore (ed). Electrophoretic and Isoelectric Focusing Techniques in Fisheries Management. CRC Press, Inc, Boca Raton, Florida, 107-129 p.

Birowo, S. (1983). Hydro-oceanographic condition of the Sunda Strait: A review. Proceding of Symposium on $100^{\text {th }}$ Year Development of Krakatau and Its Souronding. Lembaga IImu Pengetahuan Indonesia. Jakarta.

Dammannagoda, S. T., Hurwood, D., \& Mather, P. (2011). Genetic analysis reveals two stocks of skipjack tuna (Katsuwonus pelamis) in the north western Indian Ocean. Canadian Journal of Fisheries and Aquatic Sciences (CJFAS), 68(2), 210223.

Fatchiyah, A., Widyarti, E. L., Rahayu, S. (2011). (In Indonesian) Molecular biology, the basic principle of analysis. Penerbit Erlangga. Jakarta.

Ferris, S. D. \& Berg, W. J. (1987). The utility of mitochondrial DNA in fish genetics and fishery management. In: Ryman, N., Utter, F. (eds.) Population genetics and fishery management. University of Washington Press, Seattle.

Giles, J. L., Ovenden, J. R., Dharmadi, D., AlMojil, D., Garvilles, E., Khampetch, K., Manjebrayakath, H., \& Riginos, C. (2014). Extensive genetic population structure in the Indo-West Pacific spottail shark, Carcharhinus sorrah. Bulletin of Marine Science, 90(1), 427-454.

Hariati, T. (2005). (In Indonesian) Mackerel scads (Decapterus macarellus), one of the small pelagic fish species in the deep sea of Indonesia. Warta Penelitian Perikanan. Edisi Sumberdaya dan Penangkapan, 11(5), 2005, 15-18.

Hartl, D. L. \& Jones, E. W. (1998). Genetics: principles and analysis ( $4^{\text {th }}$ ed.). Jones and Bartlett Publishers. Inc, United State of America.

Hedrick, P. W. (2000). Genetics of populations (2 $2^{\text {nd }}$ ed.). Jones and Bartlett Publishers. Sudbury.

Liu, Y., Webber, S., Bowgen, K., Schmaltz, L., Bradley, K., Halvarsson, P., Abdelgadir, M., \& Griesser, M. (2013). Environmental factors influence both abundance and genetic diversity in a widespread bird species. Ecology and Evolution, 3, 14, $4683-4695$.

Miller, M. P. (1997). Tools for Population Genetic Analysis (TFPGA). Version 1.3. Department of Biological Sciences, Northern Arizona University, Flagstaff.

Nei, M. \& Tajima, F. (1981). DNA polymorphism detectable by restriction endonucleases. Genetics, $97,145-163$.

Octoriani, W. (2015). (In Indonesian) Fisheries management of purse seien fisheries based on ecological-economic (Case study: fisheries in Sunda Straits). Sekolah Pascasarjana IPB. Bogor.

Pfenninger, M., Salinger, M., Haun, T. \& Feldmeyer, B. (2011). Factors and processes shaping the population structure and distribution of genetic variation across the species range or the freshwater snail Radix balthica (Pulmonata, Basommatophora). Evolutionary Biology, 11, 135.

Santos, M. D., Lopez, G. V. \& Barut, N. C. (2010). A pilot study on the genetic variation of eastern little tuna (Euthynnus affinis) in Southeast Asia. Philippine Journal of Science, 139(1), 43-50. 
Sembiring, S. B., Tridjoko, M. \& Haryanti. (2013). Keragaman Genetik Ikan Kerapu Bebek (Cromileptes altivelis) Generasi F1 dan F3. Jurnal IImu dan Teknologi Kelautan Tropis, 5(1), 103-111.

Sofro, A. S. M. (1994). (In Indonesian) Genetic Diversity. Andi Offset. Yogyakarta.

Susanto, D., Gordon, A. L. \& Zheng, Q. (2001). Upwelling along the coast of Java and Sumatera and Its Relation to ENSO. Geophys. Res. Lett, 28 (8), $1599-1602$.

Suwarso, S., Dharmadi, D. \& Widodo, J. (2000). Biology and fishery of Malalugis biru, Mackerel Scad, Decapterus macarellus, in North Sulawesi waters of Indonesia. In The. JSPS-DGHE International Symposium on Fisheries Science in Tropical Area. Vol 10, P.552 - 557.

Tabata, K. H., Kishioka, M., Takagi, A., Mizuta, N. \& Taniguchi, T. (1997). Genetic diversity of five strains of red sea bream Pagrus major by RFLP analysis of the mtDNA D-Loop region. Journal Fisheries Science, 63(3), 344-348.

Utter, F., Aebersold, P. \& Winas, G. (1987). Interpreting genetic variation detected by electrophoresis. In: N. R. F. Utter (ed.) Population genetics and Fishery management, University of Washinton press, Seattle.
Walsh, M. R., Munch, S. B., Chiba, S. \& Conover, D.O. (2006). Maladaptive changes in multiple traits caused by fishing: impediments to population recovery. Ecol. Lett., 9, 884, 142-148.

Wilson, D. S. \& Clarke, A. B. (1996). The shy and the bold. Natural History, 9/96, 26-28.

Wyrtki, K. (1961). Physical Oceanography of the Southeast Asian Water. NAGA Report Vol 2. Scripps Inst. Oceanography. The University of California. La Jolla, California.

Wyrtki, K. (1962). The upwelling in the region between Java and Australia during the south-east monsoon. Australia Journal Marine Freshwater Resources. 13 (3), 217-225.

Zamroni, A., Suwarso \& Nugroho, E. (2014). (In Indonesian) Genetic population structure of Mackerel scads (Decapterus macarellus Cuvier, 1833) around Sulawesi based on Mt-DNA Marker. Jurnal Penelitian Perikanan Indonesia, 20(1), 3141.

Zein, M. S. A. (2007). (In Indonesian) Diversity of Mitochondrial DNA Control Areas Timor Deer (Cervus timorensis timorensis) in Timor Island, Alor and Pantar. Biota, 2(3), 138-144. 